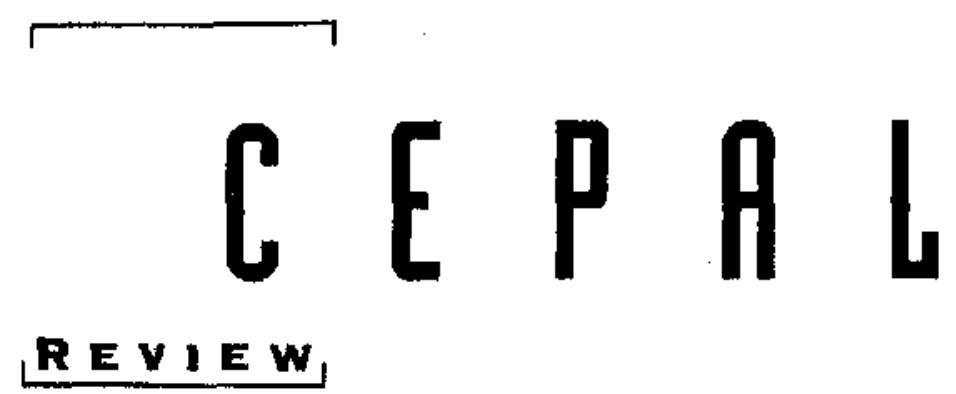

\author{
NUMEEF 65 \\ AUQUST 1998 \\ SANTIAGO, CHILE \\ O S CA ALTIMIA \\ Director of the Review \\ EUGENIO LAHEAA \\ Technical Secretary
}

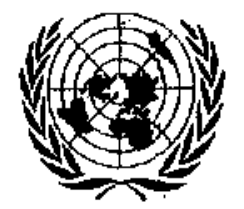


Income distribution, poverty and social expenditure In Latin Amerlca

José Antonio Ocampo

Military expenditure and development in Latin America

Eugenio Lahera and Marcelo Ortuzar

Growth, dlstrlbutive justice and social policy

Andrés Solimano

Equity, forelgn investment and International competitiveness

Adolfo Figueroo

Tensions in Latin American structural adjustment:

allocatlon versus distribution

Daniel M. Schydlowsky

Compethliveness and labour regulations

Luis Beccaria and Pedro Galín

Latin American femilles: convergences and divergences in models and pollcles

Irma Arriagada

Free trade agreements and female labour: the Chilean sltuation

Alicia Frohmann and Pilar Romaguera

Macroeconomic trends in Paraguay from 1989 to 1997:

consumptlon bubble and financial crisis

Stephane Straub

The strategies pursued by Mexican firms in their efforts

to become global players

Alejandra Salas-Porras

Pegulating the private provision of drinking water and sanitation services

Terence R. Lee and Andrei S. Jouraviev

Quallty management promotion to Improve competitiveness

Hessel Schuurman

Recent ECLAC publlcations 


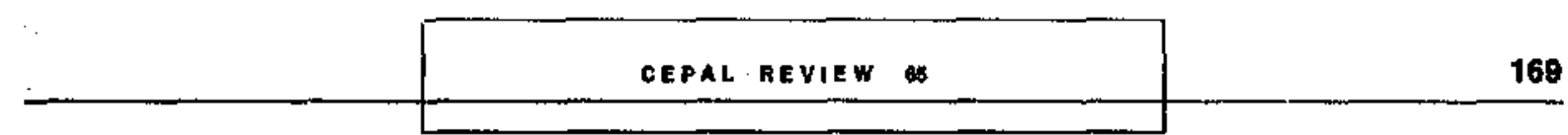

\section{Quality management promotion to improve competitiveness}

\section{Heosed Schuurman}

Former Associate Expert in the UNIDOAECLAC

Division of Production,

Productivity and

Management, ECLAC.
The author aims to demonstrate the importance of quality issues in national strategies for increased productivity and competitiveness in Latin America. Quality is an important factor in today's increasingly globalized and liberalized markets, and the application of quality management techniques is therefore considered to make a positive contribution to the competitive performance of countries, economic sectors and individual organizations. Since competitiveness contributes to sustainable development, the widespread diffusion and implementation of quality management seems desirable from a national point of view. In recent years, Latin American governments have shown a growing tendency to establish programmes that promote and support the diffusion of quality management techniques. Thus, quality issues will play an increasingly important role in the social and economic development objectives of the countries of the region. The implementation of total quality management (TQM) innovations has not proved to be easy or rapid, however: for example, in Latin America the diffusion of the ISO 9000 standards for quality systems has been less rapid than in most other regions of the world. In the author's view, the level of quality awareness in the region has been limited by market considerations, the difficulties of enterprises in gaining access to resources, traditional management practices, and conditions at the macro level. These obstacles can be associated with market failures that occur within companies, between companies and in factor markets. Various governments have therefore chosen to promote quality management techniques in order to adjust to the releyant market failures. The article concludes with an overview of the activities that have been carried out in selected Latin American countries to enhance the diffusion of ISO 9000 quality management systems. 


\section{I}

\section{Introduction}

Quality refers to the totality of features or characteristics of a product or service that bear on its ability to satisfy stated or implied needs. Therefore the implementation of quality within an organization requires the internalization of the concept of "consumer satisfaction". Moreover, as quality failures and defects can have substantial adverse effects on an organization's resources and performance, the implementation of quality management will involve the "continuous improvement" of all the organization's activities that affect quality. The results of coninuous improvement may be improved product quality, less waste or reworking, or improved secondary labour conditions. Furthermore, the provision of quality assurances to clients has become a concept that has evolved from final product inspection, to operational process control, to quality control in the product or process design phase. Therefore, the implementation of quality control involves the overall management of an organization rather than being a secondary problem of specialized departments.

Total quality management (TQM) is a management philosophy that aims to achieve improved enterprise results through the realization of objectives related to consumer satisfaction and continuous improvement. Among other aspects, TQM emphasizes measurement and monitoring, improved crossfunctional communication and external relations, quality assurance and human resources development (Rauter 1995). In order to establish both effective (consumer satisfaction) and efficient (continuous improvement) organization, a wide range of quality management techniques have been developed and applied that incorporate these TQM principles, which can guide the implementation of the different quality management techniques.

Quality has become a major factor among the competitive pressures existing in today's increasingly globalized and liberalized markets, and the application of quality management is considered to make a positive contribution to competitive performance. Competitiveness may be defined as the ability of a country or organization to generate proportionally more wealth than its competitors in world markets, as noted in World Competitiveness Report, 1995. In the next two sections, various aspects of quality management and competitiveness will be discussed at the national, sectoral and enterprise levels.

\section{II}

\section{Quality management and competitiveness}

\section{at the national and sectoral levels}

At the national level, competitiveness may be analysed according to the approach used in the World Competitiveness Report. In the 1995 version of this report, a list of $\mathbf{4 8}$ countries is presented, classified by the various factors that influence a country's international competitiveness, such as strength of the domestic economy, appropriate government policies, infrastructure, etc. In accordance with the methodology used in the report, quality aspects are primarily presented within the "management" factor (i.e., the extent to which enterprises are managed in an inno- vative, profitable and responsible manner), and to a lesser extent within the "science and technology" and "people" factors (scientific and technological capacity, together with the success of basic applied research; and the availability and qualifications of human resources). Therefore, quality may be identified as a factor that contributes to a country's com-

\footnotetext{
I World Economic Fonum, Internationat Management Development Institute, 1995.
} 
petitiveness. ${ }^{2}$ For example, quality management techniques have been identified as being an important factor in the economic success of Japanese companies, by making their production more flexible, productive and more competitive.

Figure 1 shows the relation between TQM and competitiveness. The numbers on the horizontal axis correspond to the countries' place in the overall competitiveness ranking presented in the World Competitiveress Report 1995. Executives in each of the participating countries were asked to rate the use of TQM in their respective country on a scale from one to ten. The results are reflected on the vertical axis. The overall tendency (linear mean) of the relationship between TQM and competitiveness indicates that TQM practices are increasingly applied as the countries are rated more competitive. ${ }^{3}$ The non-linear relationship between competitiveness and TQM is assuredly due to the fact that TQM is not the only factor that determines international competitiveness.

The improved aggregate competitive performance of the economic sectors of a country is not limited to individual firms in those sectors. It also depends on the application of quality management within entire production and/or commodity chains. For example, the competitive performance of a company will be influenced by the competitive performance of its suppliers and other subcontractors (consisting of backward and forward linkages in the same or connected sectors) and its degree of communication with them. Competitive industrial development theories therefore place emphasis on the promotion of intra-firm reorganization and the establishment of enterprise networks. The Organization for Economic Cooperation and Development (OECD) notes that the economic success of such enterprise networks has not come about through advantageous access to low-cost factors of production, cheap labour, capital and/or land but rather through particularly effective social and economic organization of those networks (OECD, 1993).

\footnotetext{
${ }^{2}$ In order to determine how far quality contribunes to competitiveness, the author has analysed the tables in the World Comperitiveness Report and has estimated that factors associated with quality management account for about $12 \%$ of the overall calculation of the competitiveness ranking of countries. It should be noted that this figure is the resule of a very rudimentary exercise and is purely indicative.
}

FIGURE 1

TQM and competitiveness

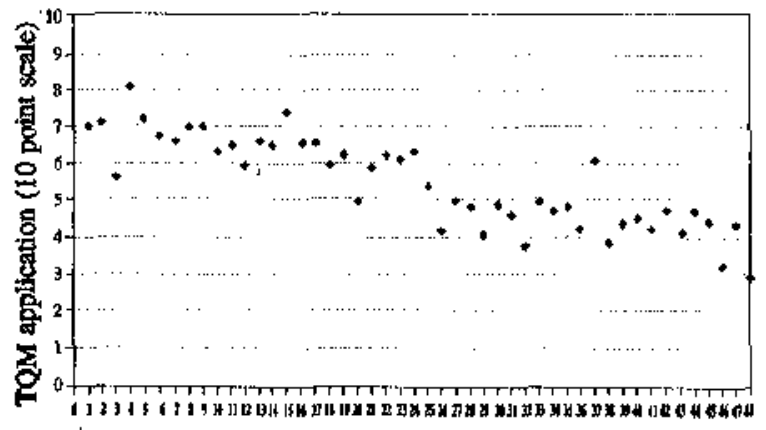

Country code competitiveness ranking

The TQM principles that seem especially relevant for achieving the intemalization of quality issues in the production chain are: communication and dissemination of information, measurement and monitoring, and compliance with quality assurance standards. ${ }^{4}$ In order to face increased global competitiveness pressures large companies determine their core business areas (according to their competitive advantages) and then often subcontract or outsource all other activities. Hence, as large companies become more dependent on suppliers they look for reliability, improved communication and long-term relationships with the latter. The internalization of quality management within the production chain can result, inter alia, in reduced transaction costs and increased flexibility and quality innovations throughout the economic sector in question, thereby contributing to increased sectoral competitiveness. For example, Xerox (copying machines) trained selected suppliers in statistical process methods and operational quality management techniques. As a result, over a period of two years net production costs went down by $10 \%$, the proportion of products not conforming to specifications decreased by $93 \%$, and the costs and time needed for the development of new products were reduced by 50\% (Burnt, 1990).

\footnotetext{
${ }^{3}$ The names of the countries corresponding to the numbers in figure 1 may be found in World Economic Fonum, Intemational Management Development Institute, 1995, or in Schuurman, $1997 \mathbf{a}$.

${ }_{4}^{4}$ The contribution of quality issues to the competitiveness of industrial sectors can be determined through the competitiveness analysis methods developed by Porter (1980).
} 


\section{III}

\section{Quallty management and competitlveness}

\section{at the enterprise level}

The crucial issue determining the competitive success of a company is its ability to integrate the results of quality improvement (crucial for consumer satisfaction) with profitability (the management's concern). In open economies, companies that are relatively more competitive than their rivals expand their market share because consumers are satisfied with specific characteristics of their products or services. ${ }^{5}$ Consumer satisfaction may be associated with (one or more) of the following elements of an organization's products or services (Pandora, 1989):

i) A reasonable price: The price of the product should be in line with the need the client has for the product.

ii) A good product: The quality of the product needs to be reliable or conform to predetermined specifications.

iii) A reasonable delivery time: The client needs to have the product within a certain time frame, otherwise it has no value for him.

iv) A unique product: Everybody wants a product or service that is just a little bit different or that exactly meets his individual needs. This requires that manufacturers be capable of meeting this demand for product diversity.

v) A new product: Consumers change old products, even though they may have the above characteristics, for products that are better, faster, in fashion, more modern, stronger, contain the latest materials, etc.

Hence, the competitive performance of companies in (global) consumer markets will be determined by their capacity to simultaneously deal with such factors of competition as efficiency, quality, delivery time, flexibility and innovation (Fleury, 1995; Maas,

5 Consumer satisfaction is especially important in markets where supply exceeds demand. Global markets which are litexally swamped with products and services put consumers into the position to choose.
1992; Pandora, 1989). ${ }^{6}$ As we shall below, quality management techniques may be applied in each of these areas of competition. To put it simply, competitiveness at the enterprise level may be nothing more than applying the concept of continuous improvement to all those parámeters that determine the relevant competition factors.

\section{Efficlency: a reasconable price}

As a competition factor, efficiency (price) requires that the production function -i.e., the mathematical relationship between quantities of inputs and outputs- operates as cost-efficiently as possible. For example, the optimization of capital and labour productivity has led to economies of scale where maximum efficiency is sought through minimal production costs per unit ontput. With regard to quality management and efficiency, attention conld be given to -among other things- minimizing waste and the amount of products that do not conform to specifications, decreasing material and product waiting times (dead time), and reducing the amount of stocks (materials or products).

Various management concepts have been applied to achieve higher production efficiencies. Those developed at the beginning of the twentieth century, in which the production process is organized through a detailed division of labour, with each employee performing a specific sub-task along the assembly line, ane particularly well known and widely used. Although this "Taylorism" or "Fordism" has led to large efficiency increases, it has also established a division hetween "doing" and "thinking" at the workplace. The organization of "thinking" has resulted in the extensive hier-

\footnotetext{
6 It should be considered that cvon though the factors ane discussed from their chronological evolution, they are highly interlinked. For example, application of quality techniques and innovations can lead to increased efficiency, and decreased delivery time may be the result of improved flexibility.
} 
archical pyramid of responsibilities and power relations that characterizes traditional management practices. Within this pyramid the product is passed on to the consumer through the different functional departments. In every department supervisors at different levels take decisions concerning their own functional responsibility, often without being concerned about the effects that those decisions can have on the performance of other departments, clients and other end-users. For example, a production department may be more concerned with achieving good unit production costs than with the losses that may be generated in storage because of over-production.

Leñero (1995) estimates that within such functional organizational frameworks, the total duration of the product generation process up to the product's delivery to the end-user. (also called lead time) is $100 \%$ to $200 \%$ greater than the real duration of the activities needed to perform the process. In other words, the dead time of a product can be $100 \%$ to $200 \%$. Such inefficiencies have been well described by Hammer and Champy in their book "Reengineering the Corporation" (1993), in which a "fundamental rethinking and radical redesign of business processes to achieve dramatic improvements in critical contemporary measures of performance such as cost, quality, service and speed" is proposed. Process redesign concentrates on major processes with crossfunctional boundaries and goes beyond merely improving existing processes, as it continuously asks the question: "should we be carrying out this particular task, and if so, with what labour organization and participation?" Reengineering has evolved because the new skill requirements of the work force and rising consumer expectations have made the division between "doing" and "thinking" unworkable (MacDonald, 1995), A second factor often associated with reengineering concerns modernization through the application of modern information, (tele)communication and organizational technologies. Clearly, solutions for increased competitiveness must include both organizational and technical innovations. ${ }^{7}$

In order to achieve continuous improvement, most companies concentrate on internal processes and methods. However, benchmarking techniques may be used to determine the relative position of the

\footnotetext{
7 The present discussion will be lintited to the first of these aspects. However, many organizational innovations will have consequences for technical innovations, and vice versa.
}

company as compared to rival companies which are applying the latest (quality management) innovations. There are two types of benchmarking. The "product-oriented" type addresses cost reduction through the evaluation of products and services, while "process-oriented" benchmarking examines production and management processes. In general, benchmarking involving the search for opportunities within the company's environment has resulted in efficiency increases and cost reductions (Zairi, 1996). If process-oriented benchmarking is applied within a culture of TQM it can lead to increased organizational efficiency along the lines of consumer salisfaction and continuous improvement.

The term "downsizing" refers to the discontinuation of specific functions or areas that are not part of. the cone competences or real competitive advantages of the enterprise. Due to competitive pressnres, enterprises are specializing in what they do best and subcontracting related activities (ontsourcing). The term "delayering" means reducing the number of hierarchical levels and, like downsizing and outsourcing, may result in increased efficiency and flexibility.

It should be noted that reengineering, actualization, downsizing, outsourcing and delayering often aim to secure increased efficiency through fundamental, radical and/or drastic organizational changes. The results may be visible in the short term, and reductions in personnel are common. However, it is reported that more than $30 \%$ of companies have failed to implement reengineering principles or to attain efficiency benefits (Champy, 1995). In the specialized literature, there is some consensus that reengineering principles should be combined with those of total quality management. ${ }^{8}$ In this respect, it is recommended that any organizational change should be accompanied by human resources development. This is crucial for ensuring proper understanding of the new organizational principles and technologies.

\section{Quality: a good product}

Total quality management principles can provide guidance for the application of management practices relating to all the factors of competition mentioned above. This means that the TQM philosophy and

\footnotetext{
${ }^{8}$ See, for example, MacDonald (1995) and Lefiero (1995),
} 
quality management techniques are at the very heart of enterprise-level competitiveness. A study made among 700 companies in Western Europe (KD, 1996) reports that companies which have effectively applied TQM principles are characterized by higher consumer satisfaction, increased personnel participation, greater quality awareness, cost reduction and improved business results.

Quality management generally implies the systematic planning, control and improvement of quality by designing an appropriate organizational structure for the application of quality management techniques, which may be referred to as a "quality management system". A system of this type involves a company's organizational and responsibility structure and the procedures, processes and resources for implementing quality management. The Iso 9000 international standards provide a number of different quality assurance models for quality management systems. For example, the Iso 9001 standard consists of 20 guidelines for a quality system, covering the design, production and final inspection phases. An objective, accredited third party may be responsible for verifying whether a system effectively complies with ISo 9001 . Such quality system certification is given after a third-party certification audit. In general, both internal and external quality management andits are common practices. An ISo 9000 certified company can use that certification to promote its products or services among its clients, and the implementation of an 1509000 quality system should be viewed, as a valuable intermediate step towands achieving TQM (Q Review, 1993). Within production chains or enterprise networks, ISO 9000 standards are in line with the demand for process- oriented quality assurance schemes. Various surveys among ISO 9000 certified companies indicate that about $65 \%$ to $75 \%$ encourage their suppliers and subcontractors to seek certification as well. These are some of the reasons why Iso 9000 may be associated with competitiveness (Schuurman, 1997a),

In view of the tendencies towards outsourcing, it is increasingly important that an organization should be able to assure or guarantee its clients that it is capable of conforming to certain predetermined quality standards. In seeking decreased transaction costs, quality assurance schemes have moved away from product-oriented approaches (final inspection) to quality management standards, of which iso 9000 is the most popular. This reflects the assumption that good quality process management results in good quality products (ISO, 1993), although this is not always true, as the standard does not guarantee compliance with absolute quality performance indicators or specifications.

Quality cost calculation structures may be established in order to control and evaluate an organization's effectiveness in seeking zero quality defects. The Activity Based Costing (ABC) technique may be a useful methodology for facilitating the establishment of quality cost calculation systems at the activity (process) level. Quality costs may be classified as the costs of prevention and quality assurance activities and the costs associated with internal and external faults. Optimal expenditure on quality hence involves balancing preventive and assessment costs, on the "costs of quality" side, against the estimated benefits deriving from the reduction of quality failures, on the "costs of non-quality" side (Van de Broek, 1991).

It has been reported that expenditures on the establishment and maintenance of quality management systems (classified as preventive and assessment costs) help to reduce the costs due to unacceptable quality. For example, it is estimated that in mediumsized to large companies the cost of iso 9000 quality system implementation and certification is roughly between $0.5 \%$ and $1.5 \%$ of their total tumover, whereas the reported tangible quality cost savings and reductions, as a percentage of turnover, are several times greater (Schuurman, 1997b). An advantage of establishing quality cost calculation structures is that they can show tangible results which can be used to justify and facilitate the implementation of (new) quality management techniques. Another type of quality cost benefits may involve the quantification of the results of quality management. Such benefits may take the form of significantly improved product performance, conformity with specifications, durability and serviceability: all improvements that may lead to increased consumer demand and market share. These improvements may be termed "revenue enhancers", although it is difficult to ascribe them solely to quality management implementation (Winchell, 1987; Spitzer, 1993).

Some of the conclusions concerning quality cost issues cited in the literature are:

i) Quality costs may account for a significant percentage of total turnover. A study in the Netherlands concluded that quality costs differ from one 
industrial sector to another but averaged $10 \%$ of turnover. A study among 54 companies in France reports that quality costs vary from $5 \%$ to $23 \%$ of turnover (Van de Broek, 1991). The ISO estimates that the costs of poor quality in developed countries range from $15 \%-25 \%$ of turnover, while they are likely to be hìgher in developing countries (ISOUNCTAD/GATT, 1993).

ii) Between $60 \%$ and $70 \%$ of quality defects detected on the shop floor are directly or indirectly attributable to errors in other areas such as design, engineering, purchasing, production, packaging, dispatch and transportation, although almost all traditional quality assurance activities (inspection) are directed to the shop floor (Nakamura, 1992).

iii) After taking actions for quality improvements (along the lines of TQM, preventive and assessment measures), quality costs may decrease significantly. In the Netherlands, companies have achieved savings that average $3 \%$ of total turnover (from $10 \%$ to $7 \%$, see Van de Broek, 1991). It is estimated (TOV Rheinland Chile, 1995) that an organization can decrease its quality costs from $23 \%$ to about $6 \%$ during a period of 4-5 years: i.e., the time needed to implement a system of total quality management. ${ }^{9}$

The majority of the costs in the TQM implementation phase are associated with preventive and assessment activities, which are well compensated by the costs of quality defects (scrap, reworking, guarantees).

\section{Reasonable delivery times}

As well as providing the client with the right price, quantity and quality, short and reliable delivery times for products and services can be the next crucial factor in achieving better competitive performance for an enterprise. Especially in the case of clients who apply operational quality management techniques in the production process (such as Just In Time procechres), the delivery time for material supplies is very important and is often related to optimization of the logistic processes of the company which may have consequences for the lead time in functional areas other than distribution, such as production and new product and process development (see section 4

\footnotetext{
${ }^{9}$ For more details on the phases in the implementation of a total quality management system, see section IV below.
}

below). Choosing a suitable organizational structure, or the way (process) functions are grouped, is important in optimizing delivery times. For example, the organizational structure may be classified by the type of activity (function), product or service and/or geographical location.

Technical and statistical quality management methods are often used to control and improve logistical processes. Another technique involves the relocation of the client order supply point (COSP), which is the last important material supply point from which the client's order may be fulfilled. By relocating the cosp further upstream in the production system (closer to the final product), shorter and more reliable delivery times may be achieved (Pandora, 1989). Thus, for example, by locating the cosp at the "stock of main components", the final product may be assembled from these main components when client orders are received. Assernbly time will then form the main component of delivery time. A more integral management concept that allows the management of time factors within an organization is "time-based competition" (Wildschut, 1993).

\section{Fexibillty: product dlversity or uniquenese}

Flexibility refers to the ability to deal with the increasing differentiation and volatility of markets. In the present discussion flexibility is associated with the capacity for the timely production of the right variety and quantity of products according to market demand. The incorporation of flexibility will have consequences for the organization, structure and planning of the production process, with efficiency, quality and delivery time as important parameters. Obviously, new products are not excluded from this approach, and therefore flexibility and innovation may be overlapping terms. Flexibility in the production process in order to respond adequately to market demands usually means shorter periods of adjustment, variations in the amount of inputs and cost-oriented strategies, while innovative flexibility normally involves longer adjustment periods, improved human resources, productivity gains and strategies oriented towards new products and processes (Reinecke, 1996).

Management of flexibility is important, because consumers demand large numbers of product families and varieties and moreover consumer demand fluctuates in time. This requires batch production, and the 
amount of non-productive hours in which installations have to be adjusted to produce new batches can be substantial. Fluctuating demand can be tackled by establishing stocks of finished products, but this solution may lead to high costs and risks, considering the large variety of products and rapidly changing market demands. As producers need to deliver their products to their clients promptly, control of the lead time in the production process is crucial. This requires management of the various types of flexibility, such as:

i) Product flexibility (the ability to change easily to produce different varieties of products);

ii) Flexibility of the installed machinery (the ability to make different parts within a product family);

iii) Process flexibility (the ability to produce a product family in different ways, for example by using different materials);

iv) Volume flexibility (the ability to accommodate to changes in production volume efficiency);

v) Functional flexibility (the ability of the employees to perform different tasks in order to make possible the above types of flexibility);

vi) Numerical flexibility (flexibility of the number of employees on the payroll, overtime, flexible timetables, subcontracting); and

vii) Flexibility of incentives (wage, promotional and bonus schemes to reward employees for their group or personal achievements).

There are various management techniques that can be applied to make the production process more flexible. These include, among others, just-in-time management (JT), kanban, and cellular factory layout. JT involves a form of organization of production that aims to produce the right quantity at the right time at the right quality. IIT is often thought of in terms of relations with suppliers, but internal JTr is probably a necessary precondition for external JT. Internal JTT requires a reduction in lot sizes, and production is most efficient when flows of materials are simple and straightforward; it also requires a muiti-skill and multi-tasking labour force. Extemal IT involves the establishment of subcontracting tiers that deliver in small lots, as well as coordination of government institutions responsible for implementing long-term economic and industrial policies (Japan).

Kanban is a form of inventory and production control using simple manual and clerical procedures.
Kanban utilizes the demand in the next production step as a pull system and operates best in an environment of steady demand and limited number of products. Cellular factory layout establishes "mini-factories" which, together, unify various processes and installations capable of producing a complete family of products (ITT and kanban procedures are often applied ton). Clearly, these operational techniques involve increased responsibilities of the operators, and ensuring that workers are sufficiently skilled and trained is crucial to the successful implementation of these techniques (Vispo, 1994).

\section{Innovation: new products}

In recent decades, companies that operate in global markets have competed successively in terms of price, quality, delivery time and flexibility. In view of the tendencies towards larger and more open markets and increased consumer purchasing power, consumer demand in global markets is likely to shift to products that are of higher quality, more unique and incorporate the latest innovations. Moreover, companies will specialize in sub-markets through advanced technology and automation, resulting in more rapid ageing and depreciation of products and machinery. In the near future, it may therefore be expected that the determining additional competition factor in global markets will be innovation.

As already noted, markets are subject to rapid changes, shortening the life-cycle of products. Producers need to be able to rush changes onto the market by optimizing the amount of time needed to design, develop and launch new products or processes. For example, one indicator of innovation may be the proportion of products in the overall product spectrum which have been introduced to the market within the last two to four years (Kaplinski, 1995). The current meaning of design is coming increasingly close to that of product development: not only is it necessary to comply with technical and functional product characteristics, but the successful marketing of the product also needs to be assured. Such criteria are closely related to the wishes of the consumer and include aspects such as image, recognition and form. After taking the decision on a new product concept, almost $80 \%$ of the decisions subsequently taken concern production costs and use. Moreover, the R\&D and design phases determine about $70 \%$ of the total quality costs involved later (Maas, 1992). 
The rapid development of new processes and products depends to a large extent on the firm's capacity to benefit from its knowledge, both internally and within its direct surroundings. This means that ideas for improvement can come from almost anyone, including consumers, workers, suppliers, staff and managers. Innovation thus depends on the pro-active involvement of different functional areas and calls for the right balance between creativeness and control. On the one hand, rigid bureaucratic processes inhibit creativeness, but on the other hand, lack of discipline can lead to chaos and unprofessional attitudes. Innovation (R\&D, product development) is often a longterm process that may involve considerable investments and bring fundamental structural organizational changes. This highlights the importance of the strategic planning of quality management innovations.
In general, project formulation and quality management are the right instruments for controlling these processes of change and innovation. Quality function deployment (OFD) is a systematic planning method for integrating customer satisfaction into product and process development. Another similar technique that places emphasis on quality control in the design phase has been developed by Taguchi. Both are planning techniques that aim to identify essential design aspects and reduce manufacturing costs and lead time, securing better product quality at less cost. Both are often the responsibility of crossfunctional product teams. Quality control circles (cross-functional and cross-hierarchical working groups) also seek to identify opportunities for innovation in a general sense and ane not necessarily limited only to the design process.

\section{IV}

\section{Implementation of total}

\section{quality management}

In order to implement TQM, enterprises must formulate and implement strategies related to quality and must be able to adapt these strategies at any time in response to changing market, client and supplier conditions. The strategic planning of quality aims to guide performance along the entire value chainfrom research and development $(R \& D)$ through production and marketing to after-sales services, both at the company and the inter-company level (Kaplinski, 1995): As discussed in the previous section, the concepts of consumer satisfaction and continuous improvement are the basis for competitive performance, which in turn may be broken down into the following elements:

i) The definition of core competences and the maximization of capital and labour productivity (efficiency);

ii) The pursuit of zero quality defects in organizational activities, services and products (quality); time);

iii) The optimization of total lead time (delivery

iv) The organization and control of production inputs and outputs to cope with diverse and fluctuating market demand (flexibility); and v) The organization and control of product design and development in order to ensure timely responses and anticipate changing market conditions (innovation).

A possible company strategy for implementing different quality management techniques is presented in box 1. Basically, implementing TQM implies the pro-active application of the concepts of consumer satisfaction and continuous improvement in the most effective and efficient way. It may be seen from box 1 that the combination of reactive-reactive strategies implies low efficiency and little effectiveness (taking unnecessary measures in the wrong way). A highly efficient but ineffective organization takes unnecessary measures in the right way, while an effective organization with limited efficiency takes necessary measures in the wrong way. In contrast, a pro-active - pro-active combination would mean that the company meets specific quality and competition criteria both internally and externally (taking the necessary measures in the right way).

During the gradual implementation of TQM, organizations will be switching between the conditions shown in the second, third and fourth quadrants of 


\begin{tabular}{|c|c|c|}
\hline \multicolumn{3}{|c|}{$\begin{array}{c}\text { BOX } 1 \\
\text { ENTERPRISE-LEVEL STRATEOIC PLANNINO FOR THE IMPLEMENTATION OF QUALITY MANAOEMENT }\end{array}$} \\
\hline & & More efiective \\
\hline & Reactive & Pro-actlve \\
\hline Reactive & $\begin{array}{l}\text { NO STRATECY } \\
\text { No quality system } \\
\text { Quality costs unknown } \\
\text { Traditional perception of quality } \\
\text { * quality oosts more } \\
\text { * quality decreases productivity } \\
\text { * quality means inspection }\end{array}$ & $\begin{array}{l}\text { CUSTOMER SATISFACTION } \\
\text { Inventory of clients' wishes } \\
\text { Delivery time. JIT } \\
\text { Quality assurance } \\
\text { Extemal audits } \\
\text { Benchmarking } \\
\text { Anticipation of new quality standards and prevention } \\
\text { of technical barriers to trade } \\
\text { Extealat communication and dissemination of information } \\
\text { in the production chain } \\
\text { Diffusion of quality policy to the society at large }\end{array}$ \\
\hline Pro-active & $\begin{array}{l}\text { CONTTNUOUS IMPROVEMENT } \\
\text { Reengineering of core processes } \\
\text { Delayering, downsizing, outsourcing } \\
\text { Establishment of a quality system } \\
\text { Training } \\
\text { Delegation of responsibilities } \\
\text { Statistical process methods } \\
\text { Quality cost calculation stnucture } \\
\text { Internal audits } \\
\text { Optimization of Jead time } \\
\text { Just-in-tirne system, kanbran } \\
\text { Evaluation of suppliers }\end{array}$ & $\begin{array}{l}\text { TOTAL QUALTY MANAGEMENT } \\
\text { Systematic evaluation of quality performance } \\
\text { Contimuonis readjustment of processes, products and services } \\
\text { Reliable supplier base } \\
\text { Teamwork } \\
\text { Quality function deployment } \\
\text { Quality control circles } \\
\text { Leadership and dynamic quality culture } \\
\text { Strong emphasis on human resources management } \\
\text { Employes satisfaction } \\
\text { Participation in quality prize schemes }\end{array}$ \\
\hline $\mathbf{M}$ & & \\
\hline
\end{tabular}

box 1 , depending on their internal resources and the relevant competition factors in the markets in which they operate. Intemalization of consumer satisfaction often involves the reorganization of various departments concerned with key processes in the production system, which in turn requires increased crossfunctional cooperation. Once this is established, the functional departments seek improved business performance and cost efficiency through the application of management tools that enable the continuous improvement of their activities. The driving force for sustaining the total quality process is the development of an appropriate culture within the organization. This emphasizes the importance of leadership by the management in promoting the total quality culture and the implementation of such leadership through a quality strategy (Technovation, 1994).

According to a survey among 700 Dutch companies (Dutch Institute for Quality, 1996), companies may be classified in different phases, according to the extent or orientation of their quality management efforts:

Phase 0: Non-existent or limited quality management.

Phase 1: Product-level management (inspection of product quality).

Phase 2: Process-level management (management of quality aspects in processes pertaining to the different functional areas).

Phase 3: Systemic quality management (management of integrated quality systems, such as ISo 9000 ).

Phase 4: Production chain quality management (quality management regarding clients and suppliers).

Phase 5: Total Quality Management (integration and simultaneous application of all the above quality management phases). 


\section{V}

\section{The importance of quality management,}

\section{and the obstacles to its implementation}

The European Commission (1995) has classified quality awareness in Japan and the USA as "excellent" and "good", respectively. This is confirmed by the main findings of a study (American Quality Foundation, 1991) on the quality management practices applied by more than 500 firms in North America, Japan and Germany. This study reported that:

i) More than $50 \%$ of the firms studied evaluate the business consequences of their quality performance at least monthly;

ii) $40 \%$ of the companies attach prime importance to customer satisfaction in strategic planning;

iii) $30 \%$ of United States and Japanese companies attach prime importance to analysis of their competitors' performance (benchmarking);

iv) $90 \%$ of Japanese and $25 \%$ of United States companies continuously reengineer their production or service processes; and

v) All companies view cross-functional quality teams as the best way of increasing employee involvement.

In most European countries, quality awareness is classified as insufficient. A survey made by the Dutch Institute for Quality (1996) reports that $45 \%$ of the 700 companies studied focus their quality strategy on the primary process and related subprocesses. Very few companies are concerned with social objectives and do not seek process improvements through communication with clients and suppliers. According to the survey $70 \%$ of the companies are positioned somewhere in phase 2 or 3 of the quality management classification given in section IV above. Only $2 \%$ of the participating companies consider that they have achieved total quality management, while $13 \%$ are in phase 4 . The remaining $15 \%$ are in phase 0.

In practice, it is difficult to embody quality is" sues firmly in company strategy, principally because of the difficulty of defining tangible objectives relating to the implementation of quality management issues. Also, the implementation of organizational innovations such as TQM is less systematic than in the case of technological innovations, because the imple- mentation of quality management techniques involves changes in personnel attitudes and relations, affects almost everybody in the organization, changes the structure of responsibilities, requires a high level of management commitment, and leaves room for different interpretations. The application of quality management techniques therefore involves complex and far-reaching organizational innovations and is often carried out in a sequential manner. It consists of a learning process of a gradual and cumulative nature. Therefore, it may be observed that most companies which have introduced quality management have done so through trial and error and have progressed through a steady build-up of capabilities, beginning in specialized areas and later extending to company strategy and external relations (Fleury, 1995).

In the light of the TQM ranking presented by the World Competitiveness Report and the small number of companies with certified Iso 9000 quality systems $^{10}(1 \%$ of the total; see also table 1$)$, it may be concluded that the application of integral quality management techniques and the average level of quality awareness in Latin America is limited or occasional. In order to understand some of the factors underlying this, the obstacles to the implementation of quality management in Latin America will be discussed below. ${ }^{1}$ The main question in the current discussion is whether the widespread use of quality management practices is only a matter of time, since there is a sequential process of learning involved, or whether there may be a variety of specific factors which inhibit the systematic implementation of quality management techniques.

\footnotetext{
${ }^{10}$ The amount of ISO 9000 certificates in a country is assumed to indicate a tendency towands the adoption of quality management techniques (Schuurman, 1997a).

11 The information presented here is taken from Fleury (1993 and 1995), Humphrey (1993 and 1995) and Kaplinski (1993 and 1995), unless otherwise stated.
} 
TABLE 1

Selected reglona and countrlea: Companles

with cortitied 1509000 quality syatema

(Number of companies and percentages)

\begin{tabular}{|c|c|c|c|c|c|}
\hline Region/couniry & \multirow{2}{*}{$\frac{\text { January } 1993}{18577}$} & \multirow{2}{*}{$\frac{\text { June } 1994}{36832}$} & \multirow{2}{*}{$\begin{array}{c}\text { March } 1995 \\
44107\end{array}$} & \multirow{2}{*}{$\frac{\text { December } 1995}{52591}$} & \multirow{2}{*}{$\frac{\text { Percentage }}{41}$} \\
\hline United Kingdom & & & & & \\
\hline Continental Europe: & 4515 & 18577 & 27810 & 40019 & 31 \\
\hline Germany & 790 & 3470 & 5875 & 10236 & \\
\hline France & 1049 & 3359 & 4279 & 5535 & \\
\hline The Netherlands & 716 & 2718 & 4198 & 5284 & \\
\hline Italy & 188 & 2008 & 3146 & 4814 & \\
\hline Spain & 43 & 586 & 942 & 1492 & \\
\hline North America: & I 185 & 4830 & 7244 & 10159 & 8 \\
\hline United States & 893 & 3960 & 5954 & 8762 & \\
\hline Pacific: & I B62 & 4628 & 6479 & 10526 & 8 \\
\hline Australia & 1668 & 3710 & 5299 & 8834 & \\
\hline Asla: & 692 & 3421 & 6568 & 10278 & $\mathbf{B}$ \\
\hline Japan & 165 & 1060 & 1827 & 3762 & \\
\hline Newly industrialized countries " & 382 & 1561 & 3004 & 3892 & \\
\hline India & 8 & 328 & 585 & 1023 & \\
\hline Ching & 10 & 150 & 285 & 507 & \\
\hline South East Asia" & 4 & 59 & 229 & 370 & \\
\hline Africa/Middle East: ${ }^{c}$ & 954 & 1705 & 2286 & 2340 & 2 \\
\hline Soth Africa & 824 & 1161 & 1369 & 1454 & \\
\hline Israel & 110 & 279 & 497 & 526 & \\
\hline \multicolumn{6}{|l|}{ Saudi Arabia and the United } \\
\hline Arab Emirates & 7 & 65 & 108 & 202 & \\
\hline Latin America & 39 & 533 & 873 & 1440 & 1 \\
\hline Brazil & 19 & 348 & 548 & 932 & \\
\hline Mexico & 16 & 85 & 145 & 215 & \\
\hline Total & 27824 & 70526 & 95367 & 127399 & \\
\hline
\end{tabular}

Source: ISO 9000 News, 1996.

"The percentages of certificales issued up to December 1995 were: Taiwan, 35\%; Singapore, 30\%; Hong Kong, 19\%, and South Korea, $16 \%$.

'The percentages of certificates issued up to December 1995 were: Thailand, 39\%; Indonesia, 34\%, and Philippines, $27 \%$.

'The majority of the certificates have been issued in South Africa (62\%), Irral (23\%), Saudi Arabia (4\%) and United Arab Emirates (4\%).

dit is estimated that by 1998-1999 approximately 225000 is 9000 certificates will have been issued.

\section{Trade and market considerations}

With the abandonment of import substitution practices by most Latin American governments in the late 1980s, intemational trade increased together with the amount of foreign direct investment. The resulting competitive pressures from international markets have brought a need for organizational and technological innovations. A sizable proportion of trade is within the region itself. In spite of the existence of various regional free trade agreements, the demand for formal quality managernent systems has been limited to certain countries and industrial sectors. This indicates that quality management and assurance in intra-regional trade is still of the product inspection type and has not (yet) been formalized along the lines of more process-oriented types of quality assurance such as iso 9000 .
Most of the consumers on domestic markets have low purchasing power and base their purchasing decisions on considerations of price rather than product quality. In those domestic markets where demand for consumer goods exceeds supply, almost anything sells. Because of the low levels of education, consumers' knowledge of quality and its implications is limited. Furthermore, the absence of international competition as a result of protectionist measures in the past has hindered the growth of national quality cultures, although the quality of imported goods is often greatly admired both in consumer and industrial markets. The current more open market regimes mean that domestic producers face competition from such imports, resulting in greater attention to quality issues (ISO/UNCTAD/GATT, 1993). 


\section{Companles' access to resources}

Generally speaking, the lack of adequate resources and the lack of quality awareness at the enterprise level are the principal obstacles to the widespread implementation of quality management techniques in Latin America. While multinationals, national economic groups and large State-owned enterprises have access to the necessary resources, this is undoubtedly more complicated in the case of small and mediumsized enterprises (SMEs), especially in times of macroeconomic instability. Stable macroeconomic conditions facilitate the definition of long-term company competitiveness strategies, foreign investment flows and investment in the modernization of equipment. Macroeconomic instability and high inflation, in contrast, limit the private sector's ability to engage in medium and long-term planning and often result in high interest rates. Related cuts in training activities and work force numbers undermine the motivation of employees to participate in the implementation of quality management, if indeed it is implemented at all.

Domestic market pressures on small and mediumsized supplier firms to apply quality management techniques generally come from their clients, through the production chain. Thus, for example, SIDERAR (a basic metals subsidiary of a large national economic group in Argentina) evaluates its suppliers according to their financial stability and their level of technological modernization (50\%) and use of quality management techniques $(50 \%)$. With regard to the latter, SDERAR may require ISO 9001 or ISO 9002 certification, depending on the type of supplier and its importance to the company's activities (Schuurman, 1997b). However, many SMEs tend to be product-driven rather than marketing-led, and therefore the focus on the customer and service quality may be secondary. In SMEs, quality system documentation is rarely seen as a priority and is often poorly organized. This leads us to conclude that their knowledge of the production function is very makeshift. Therefore, the SME sector could greatly benefit from the implementation of an Iso 9000 quality system, since these standards allow for a better definition of operational routines (Schuurman, 1997b and Ramos, 1995).

A study among SMEs in Brazil indicates that many firms and industries in traditional sectors lack the internal capacity needed to conform to the pressures for quality assurance exerted by their clients. Another survey in Brazil, carried out by the Brazilian
Micro-enterprise Support Service (SEBRAE) in 1994 among 35 small, 38 medium-sized and 37 large firms certified or in the process of certification under Iso 9000 reported that $85 \%$ of the small, $75 \%$ of the medium-sized and $55 \%$ of the large companies reported difficulties in obtaining the resources needed to implement the iso 9000 quality system. Moreover, $80 \%$ of the small, $45 \%$ of the medium-sized and $25 \%$ of the large companies needed to rely on external consulting services (ABNT (Brazilian Technical Standards Association),1996). Another survey made in Brazil (INMETROMICT, 1996) among 592 ISO 9000 certified companies reported that an average of $55 \%$ used external consulting services, while in small companies (less than 100 employees) this percentage was $70 \%$.

\section{Treditional manegement prectices}

The limited level of quality awareness in Latin America may be associated with the predominant application of traditional management practices resulting in employee resistance to change, lack of management commitment, and limited human resources development.

The introduction of quality management techniques will often require the reorganization of former responsibilities and power structures. Traditional labour practices (authoritarian attitudes, detailed division of labour) represent an obstacle to the more horizontal-oriented type of organization in which employers grant employees greater confidence and responsibilities. Even though organizational innovations can lead to improvements in production, the resistance of middle and senior management in different departments can be a major obstacle to the timely implementation of quality management. This may result in inconsistent implementation arising from the partial visions of specialized departments. This is why it is so crucial that top- level management should strongly support the implementation of a quality-oriented approach. In this respect, in most companies that have not been able to implement quality management, the problems can be traced to an inadequate commitment from the top management to provide the necessary leadership, or to the failure to give this objective sufficient attention and the necessary resources: in other words, quality management has been given a low priority and considered as a part-time activity. 
It is important that workers should understand their new responsibilities and be skilled to work with the new quality management techniques and technologies. Companies will have to meet these demands through the initiation of training and human resources development programmes. Employment practices in Mexico reveal that skill formation is often taken care of by hiring young, motivated employees who are then trained extensively on the job (Shaiken, 1994). Studies made in Brazil, however, indicate that although efforts to improve quality and productivity have achieved higher efficiency and better management practices, they have often failed to promote labour involvement and participation because of, among other things, limited training for dinect production workers. On the other hand, employers are faced with high training costs due to low educational levels and high turnover rates in SME labour markets.

\section{Macro-level analysis}

There are various factors at the macro level which may have inhibited the diffusion of quality management techniques in Latin America. Among such factors which will be briefly discussed below are insufficient institutional support and capacity, inadequate supplier/subcontractor networks, labour issues and cultural factors.

Evidence from, for example, Japan, Great Britain and Sweden indicates that the diffusion of quality management practices requires a certain institutional network. In these countries, industrial and employer associations, research institutes, and government agencies at the national and meso-levels have provided the financial resources, technological support and information needed to support the diffusion of quality management techniques. The existence of such institutional support varies greatly between the different Latin American countries (and also between different regions of countries). In many cases, the establishment of an institutional framework requires the support of governments.

The application of quality management techniques requires suppliers to change traditional delivery practices and deliver reliably in small batches of guaranteed quality, as any quality defects in buffer stocks will lead to delay. External subcontractors and suppliers of utilities may not be able to conform to the demands of the new production methods of the client company. In Brazil, for example, there are supplier firms which seem to have adapted to a sophisticated level of quality management in the auto parts manufacturing sector. They are often subsidiaries of international companies that strongly support such changes. The client firms frequently assist in the implementation of quality programmes, often with a strong emphasis on technical and operational aspects. These companies mention that full implementation of operational quality management practices (such as JT) has not been possible because large suppliers of materials and utilities (such as steel and electricity) could not guarantee quantity, quality and reliability of delivery. In addition, a sufficient level of physical infrastructure is required to operate and promote a dynamic and flexible supplier network.

Conditions in labour factor markets play an important role in the adoption of quality management: because this requires multi-functional workers, flexible production and innovation at the plant level, the responsibilities and tasks of direct production are enlarged. In Latin America, employers have been reluctant to invest in training programmes for direct production workers and have also been hesitant to improve wages and promotion opportunities, even though these have been identified as crucial factors for facilitating the commitment of those workers. In view of the importance of labour issues within quality management there seems to be scope for increasing the active involvement of labour organizations.

\section{Culiural aspects}

Brache (1988) describes the human performance system as one in which the individual receives input, produces output, and then adapts his performance in line with the consequences or feedback received. The quality of an individual's performance is affected by four factors. First, the input an individual receives affects the quality of his work. This input includes the clarity of performance expectations, the logic of work procedures, the sufficiency of skills and knowledge, and the clarity of signals (incentives) that trigger performance. Second, the positive and negative consequences of performing desired or nondesired tasks affect an individual's work. Third, an important role is played by the quality of the feedback an individual receives: the information given; when and how often it is provided; the manner in which it is given, etc. Finally, an individual's 
physical, mental and emotional capacity to perform his functions affects the quality of his work.

The establishment of a "quality culture" in an organization, then, involves clarity of company strategies and working procedures, quality awareness, and communication. In Latin America, standardization of quality issues and in-company training have been given low priority and quality awareness in general has been low; traditional management techniques have resulted in command-control communication based on hierarchy, and reward and incentive mechanisms have been limited and often not available at all to much of the work force. However, it would be hard to prove that these aspects are inherent to Latin American cultures or cannot be changed. In general, the cultural factors prevailing in societies or regions are not considered to inhibit the applica- tion of quality management techniques, because: i) almost all of the particular TQM practices have been successfully transferred between different countries and cultures, and ii) a variety of incentives have been used to support the implementation of quality management techniques (lifetime employment, paynent and promotion schemes, etc.).

This indicates that quality awareness within an organization is facilitated by neward or incentive schemes, whose specific features may depend on the cultural environment. Culture should rather be viewed as a dynamic concept that is interdependent with economic, technological, social, political and existing cultural conditions that may have a significance at both the macro and micro levels. Therefore, an adequate "quality culture" may be developed by establishing the right mix of these conditions.

\section{VI}

\section{Market failures and}

\section{government programmes}

From the above discussion, it may be concluded that even though quality management techniques have proved that they can enhance the productive and competitive performance of companies and even countries, the market mechanism alone cannot always ensure the timely and widespread diffusion of new forms of production management and organization. For example, the diffusion of ISo 9000 standards through the market mechanism has been linited, and only certain sectors and companies have adopted them (Schuurman, 1997a). Some argue that this may also indicate the efficiency of the market. However, the limited leyels of quality awareness observed in SMEs may ultimately affect competitiveness and limit the options for sustained economic growth and employment. Furthermore, as mentioned in the previous section, certain implementation obstacles at the macro level emphasize the importance of government involvement in promoting the use of quality management techniques among a broader range of economic agents.

Basically, market failures can occur within organizations, between organizations and in factor markets (Lall, 1995). Box 2 shows the impact and nature of various market failures and gives examples of possible government intervention to correct them. It may be assumed that government policies and strategies that aim to eliminate these market failures will tend to enhance the rate of diffusion of quality management instruments. Thus, for example, the governments of Japan, the United States, Brazil, Great Britain and the Netherlands have implemented competitiveness and productivity strategies which provide for the diffusion of quality management, and at the regional level a European Quality Promotion Policy has been drafted (European Commission; 1995). In the Netherlands, the Ministry of Economic Affairs estimates that an average of $15 \%$ of the total turnover of the economy is lost due to redundancies and that US\$ 1.2 billion is lost through internal quality failures annually (Dutch Institute for Quality, 1996). Investments in government programmes to reduce these figures may thus be well worth while.

Such programmes often include specific activities concerning the diffusion of the ISO 9000 standards. From a policy point of view, the Iso 9000 guidelines provide a clear, systematic and enforceable way to implement quality management and con- 


\begin{tabular}{|c|c|c|c|}
\hline \multicolumn{4}{|c|}{ Box 2} \\
\hline \multicolumn{4}{|c|}{$\begin{array}{l}\text { MARKET FALLURES AND EXAMPIES OP GOVERNMENT INTERVENTTON } \\
\text { AMMED AT DISSEMINATING QUALITY MANAGEMENT TECHNIQUES }\end{array}$} \\
\hline & \multirow{2}{*}{$\begin{array}{l}\text { Market follures } \\
\text { Impact }\end{array}$} & \multicolumn{2}{|c|}{ Government programumes } \\
\hline Type & & Nature of problem & Example of interventions \\
\hline $\begin{array}{l}\text { A. Within } \\
\text { organizations }\end{array}$ & $\begin{array}{l}\text { Little diffusion of quality man- } \\
\text { agement, especially within SMEs } \\
\text { (insufficient widespread adoption } \\
\text { of technological and organizational } \\
\text { innovations). }\end{array}$ & $\begin{array}{l}\text { Application of traditional man- } \\
\text { agement techniques; limited } \\
\text { quality awareness. } \\
\text { Limited access to resources. } \\
\text { Instificient capacity to imple- } \\
\text { ment quality management. } \\
\text { Limited demand for quality } \\
\text { assurance schemes in the } \\
\text { production chain. }\end{array}$ & $\begin{array}{l}\text { Dissernination of information. } \\
\text { Facilitation of access to technology, } \\
\text { skill and capital factor markets } \\
\text { (see type C). } \\
\text { Inprovement of institutional } \\
\text { capacity and support structure. } \\
\text { Promotion of inter-firm and } \\
\text { institutional linkages (see type B). }\end{array}$ \\
\hline $\begin{array}{l}\text { B. Between } \\
\text { organizations }\end{array}$ & $\begin{array}{l}\text { Insufficient use of quality man- } \\
\text { agement techniques throughout } \\
\text { the production chzin or in enter- } \\
\text { prise groups. }\end{array}$ & $\begin{array}{l}\text { Undeveloped inter-firm relations. } \\
\text { Inadequale capacities of supplier } \\
\text { and subcontractor infrastructure. } \\
\text { Insufficient institutional support } \\
\text { for the diffusion of organizational } \\
\text { innovations. }\end{array}$ & $\begin{array}{l}\text { Promotion of quality management } \\
\text { and quatity assurance in enterprise } \\
\text { networles. } \\
\text { Use of the purchasing power of } \\
\text { large (State-owned) organizations } \\
\text { for supplier preference schemee. } \\
\text { Promotion of linkages between } \\
\text { relevant institutions (academic, } \\
\text { economic, labour, export, } \\
\text { technological, etc.). }\end{array}$ \\
\hline \multicolumn{4}{|l|}{ C. In factor markets } \\
\hline 1. Technology & $\begin{array}{l}\text { Insufficient technical capacity } \\
\text { and support. }\end{array}$ & $\begin{array}{l}\text { Limited investment in metrology } \\
\text { and R\&D. }\end{array}$ & $\begin{array}{l}\text { Upgrading of capacity of atandar- } \\
\text { dization and metrology instituues. } \\
\text { Promotion of relevart R\&D. }\end{array}$ \\
\hline 2. Skills & $\begin{array}{l}\text { Insufficient humm resource } \\
\text { capacity and support. }\end{array}$ & $\begin{array}{l}\text { Insufficient investment in human } \\
\text { resources. }\end{array}$ & $\begin{array}{l}\text { Stimulation of relevan fuman } \\
\text { resources development (academic, } \\
\text { auditors, consultants, in-firm). }\end{array}$ \\
\hline 3. Capital & $\begin{array}{l}\text { Limited access to financial } \\
\text { resources needed to implement } \\
\text { quality management techniques. }\end{array}$ & $\begin{array}{l}\text { Commercial loans not viable } \\
\text { (high risk and interest rates). }\end{array}$ & $\begin{array}{l}\text { Establishment of economic } \\
\text { incentives. }\end{array}$ \\
\hline 4. Product & $\begin{array}{l}\text { Limited recognition of quality } \\
\text { assurance schemes in domestic } \\
\text { and international markets: }\end{array}$ & $\begin{array}{l}\text { Limited institutional harmoniza- } \\
\text { tion and standardization of } \\
\text { quality issues. }\end{array}$ & $\begin{array}{l}\text { Estabilishment of quality assurance } \\
\text { schemes that are recognized among } \\
\text { trade partners (e.g., auditor and } \\
\text { consultant registration schemes). }\end{array}$ \\
\hline Source: For a d & deseription of govemment progra & es, see Schuurman, $1997 \mathrm{~b}$ & \\
\hline
\end{tabular}

tribute to harmonization of quality in trade issues. In the United Kingdom, for example, a funding programme assisted smaller firms with the cost of engaging extemal iso 9000 consultants, and between 1988 and 1994 companies with 50 employees or less could obtain reimbursement of up to $50 \%$ of consultancy fees. Clearly, this has been a very important contributory factor in the large number of ISO 9000 certificates in that country (see table 1).

\section{Government programmes In Latin Amorlca}

The key challenge for Latin American governments is to promote industrial growth on the basis of rapid 
Brazll: Prograsion of Total Qually Managament indieators ${ }^{a}$

\begin{tabular}{lcccc}
\hline Indicator & Brazil 1990 & Brazil 1993 & USA and Europe & Japan \\
\hline Rejections (defective parts per million) & $23000-28000$ & $11000-15000$ & 200 & 10 \\
Reworking (\% of products returned for reprocessing) & 30 & $12-20$ & 2 & 0.001 \\
Technical assistance expenses (\% of sales) & 2.7 & 2.0 & 0.1 & $<0.05$ \\
Average delivery time (days) & 35 & 20 & $2-4$ & 2 \\
Average lot size & 1000 & $100-250$ & $20-50$ & $1-10$ \\
lnventory rotation (times per year) & 8 & $8-14$ & $60-70$ & $150-200$ \\
Setup time (in minutes) & 80 & $30-40$ & 10 & 5 \\
Machime downtime (as \% of time idle) & 40 & 21 & $15-20$ & $5-8$ \\
R\&D expenditures (as \% of sales) & $<1$ & $1-2$ & $3-5$ & $8-12$ \\
Training (\% of working hours/employeefyear) & $<1$ & $<1$ & $5-7$ & 10 \\
Hierarchial levels & $10-12$ & $4-8$ & 7 & 3 \\
\hline
\end{tabular}

Source: IMAM Consuliaria Ltd, cited in Frischtak, 1995.

¿Evaluation of the Brazilian National Quality and Productivity Programme from 1991 to 1994.

productivity increases in order to reduce the competitiveness gap with developed countries. In this respect, it is estimated that average total factor productivity in Latin America is 2 to 3 times lower than in the latter countries (Ramos, 1996). The governments of Brazil, Chile, Costa Rica and Mexico have also formulated and implemented programmes to promote the diffusion of quality management techniques, although these programmes have not yet been as extensive as in some of the countries of the European Union, except in the case of Brazil, where the National Quality and Productivity Programme was initiated in 1990 in order to establish a set of activities to induce industrial modernization. The Programme is coordinated by a national commission set up for the purpose and is being implemented by a large number of different ministries, institutes, business associations, State and private sector enterprises, etc. The Programme includes various activities related to raising quality awareness, disseminating quality management techniques, human resources development, improvement of quality-related technical services, and institutional articulation, as well as some selective sectoral activities (Government of Brazil, 1991).

In synthesis, the methodology of the National Quality and Productivity Programme involves:

i) An analysis of the economic environment, with an assessment of systemic and internal constraints on the competitive behaviour of industry and the diffusion of quality management techniques;

ii) The establishment of baseline quality and productivity indicators and the definition of sectoral and global benchmarks for the country; iii) The design of a campaign to sensitize society and opinion-makers to the importance of quality management techniques for the country, and the costs associated with waste and low productivity;

iv) Upgrading of the institutional organizations involved in the diffusion of quality management techniques;

v) Targeted dissemination of general information, followed by a massive training effort; and

vi) Definition of financing mechanisms to promote the widespread adoption of quality management techniques (Frischtak, 1995).

In order to evaluate the Programme, two comparative surveys were made of 950 firms in 1990 (year one of import liberalization and the initiation of the Programme) and in 1993. With the exception of the indicator referring to training, all the indicators (presented in table 2) show some degree of inprovement over this three-year period. The data indicate, however, that there is still a gap in average key productivity and quality indicators between Brazilian firms and international practice.

In view of the limited diffusion of the Iso 9000 standards and the market failures indicated in box 2, it is proposed that an Iso 9000 programme should include the following elements:

i) Dissemination of information in order to create quality awareness among a broad range of economic agents and change traditional management perceptions of the importance of quality;

ii) Support for enterprises, by facilitating their access to technical, capital and human resources factor markets; 
Box 3

LATUN AMERICA: OVERVIEW OF NATTONAL ISO 9000 PROGRAMMES IN SELECTED COUNTRIES ${ }^{a}$

$\begin{array}{ccc}\text { Formal quality } & \\ \text { Country } & \begin{array}{c}\text { and competitiveness } \\ \text { policy doctument } \\ \text { or programme }\end{array} & \begin{array}{c}\text { Dissemination } \\ \text { of information }\end{array} \\ & \text { on ISO } 9000\end{array}$

Argentina

Brazil

Bolivia

Chile

Colombía

Costa Rica

Cuba

Mexico

Peru
$(-)$

yos

(-)

yes

(-)

yes

(-)

(-)

\begin{abstract}
on ISO 9000
\end{abstract}

yes
yes
$(-)$
yes
yes
$(-)$
yes
yes
yes

yes

$(-)$

yes

yes

(-)

yes

yes

\begin{tabular}{cc}
$\begin{array}{c}\text { Support for implementation of ISO } 9000 \\
\text { quality systems and related institutional } \\
\text { infrastnucture }\end{array}$ \\
\hline $\begin{array}{c}\text { In small and medium- } \\
\text { sized enterprises }\end{array}$ & $\begin{array}{c}\text { In enterprise } \\
\text { groups }\end{array}$
\end{tabular}

Support for implementation of ISO 9000 infrastructure

$\begin{array}{cc}\text { yes } & (-) \\ \text { yes } & \text { yes } \\ (-) & (-) \\ \text { yes } & \text { yes } \\ \text { yes } & (-) \\ (-) & (-) \\ (-) & (-) \\ \text { yes } & (-) \\ (-) & (-)\end{array}$

Source: Information gathered by the author during missions.

' (-) means information not available or not found; programmes of this type may possibly exist.

iii) Support for Iso 9000 implementation and certification in enterprise networks in order to promote the diffusion of quality assurance concepts in production chains and institutional frameworks; and

iv) Consolidation of the national institutional structure to support the implementation, certification and international recognition of the iso 9000 standards (Schuurman, 1997b).

Box 3 presents an evaluation of Iso 9000 programme activities (according to the programme elements described above) in selected Latin American countries, ${ }^{12}$ from which it may be concluded that:

i) Government agencies in almost all the countries surveyed have supported activities concerning the dissemination of information on the iso 9000 standards, but this has not yet resulted in the widespread diffusion of certified ISO 9000 quality systems.

ii) Several governments have acknowledged the existence of market failures in capital and human resources factor markets and have established economic incentives, credit lines, training and technical support activities to stimulate Iso 9000 implementation and certification.

12 The reader is referred to Schuurman (1997a,b) for more information and references on matters dealt with in this section. iii) The governments of Brazil and Chile have initiated and supported projects aimed at promoting the use of quality management techniques in specific groups of enterprises in the production chain. For example, in Chile, government projects aim to develop quality assurance activities in the supplier/ subcontractor network of a large company, thereby creating a situation from which both will benefit. In Brazil, large companies and organizations in the public and private sectors have used their purchasing power by initiating preference schemes for ISO 9000 certified suppliers and contractors.

iv) Most governments are developing -or have already established- national Iso 9000 accreditation and certification schemes.

In short, there seems to be an increasing tendency among govemments of the region to establish programmes promoting and supporting the diffusion of the Iso 9000 standards and quality management techniques. This tendency shows that these governments acknowledge the existence of market failures relating to the diffusion of quality management innovations in organizations and economic sectors and are aware that such diffusion is desirable from a national point of view. In this respect, quality will play an increasingly important role in the social and economic development objectives of the countries of Latin America. 


\section{VII}

\section{Concluding remarks}

The advantages deriving from the incorporation of quality management innovations in government competitiveness strategies in Latin America may be summarized as follows:

Quality-related measures such as total quality management and quality assurance schemes can further the competitiveness of economic sectors and even entire countries competing in today's globalized markets.

A variety of quality management techniques can be associated with the parameters determining the competitiveness of companies (competition factors related to consumer satisfaction) and continuous process improvement.

A number of studies indicate that the costs of implementing quality management techniques are less that the costs that result from not applying such techniques. For example, the costs of quality defects can be as high as $25 \%$ of a company's turnover, whereas the cost of preventing such errors is estimated to be no more than $7 \%$ of that amount.

Quality awareness in Latin America is low and the application of quality management techniques is limited. Enhanced diffusion of quality management will help to reduce the gap in levels of competitiveness and productivity between Latin America and the rest of the world.

There are certain obstacles to the implementation of quality management techniques in Latin America, associated with the failure of the market mechanisms to promote adequate diffusion of such techniques, especially among small and medium-sized enterprises. Governments could seek to correct these market failures by including quality issues in their programmes for enhanced competitiveness and productivity. The Government of Brazil, for example, through its $\mathrm{Na}-$ tional Quality and Productivity Programme, has helped to improve the business performance of various domestic economic sectors (see box 3 ).

The fact that other governments in the region are taking similar measures, as for example by promoting the use of ISO 9000 quality management systems, suggests that quality issues will play an increasingly important role in the social and development objectives of Latin America.

(Original: English)

\section{Bibliography}

ABNT (Brazilian Technical Standards Association) (1996): A SEBRAE survey demonstrates ISO 9000 implementation difficulties in Brazilian companies, Revista ABNT, Rio de Janeiro, March.

Anerican Quality Foundation (1991): The Definitive Study of Best Intemational Quality Management Practices, Cleveland, $\mathrm{OH}$, Ernst \& Young.

Brache, A. (1988): The three levels of quality, Quality Progress, October.

Burnt, D. (1990): Cooperation with suppliers, Harvard Holland Review, No. 2, Netherlands.

Champy, J. (1995): Reengineering Management, New York, Hasper Collins.

Dutch Institute for Quality (1996): De stand van zaken wan integrale kwaliteitszorg in Nederland, Den Bosch.

European Commission (1995): Working document on a European quality promotion policy, DinectorateGeneral III, Brussels.

Fleury, A. (1993): Human resources and the diffusion and adaptation of new quality methods in Brazilian manu- facturing, IDS Research Report, No, 24, Brighton, University of Sussex, Institute of Development Studies (IDS).

(1995): Quality and productivity in the competitive strategjes of Brazilian industrial enterprises, World Development, Vol. 23, No. 1, Oxford, U. K., Elsevier Science Litd.

Frischtak, C. (1995): Brazilian industry's productive revolution and the dissemination of the ISO 9000 standards, Santiago, Chile, ECLAC.

Government of Brazil (1991): Programma Brasileiro da Qualidade e Productividade, Brasilia.

Hammer, M. and J. Chanpy (1993): Reengineering the Corporation, New York, Harper Collins.

Humphrey, J. (1993): Quality and productivity in industry: New strategies in developing countries, IDS Bulletin, vol. 24, No. 2, Brighton, University of Sussex, IDS. (1995): Introduction of the editor, World Development, vol. 23, No, 1, Oxford, U. K., Elsevier Science L.td. 
INMETROMICT (National Institute of Metrology. Standardization and Industrial Quality/Ministry of Industry, Trade and Tourism) (1996): Brasil $e$ a Certificafáo iso 9000, Rio de Janeiro.

Intemational Management Development Institute, World Economic Forum (1995): The World Competitiveness Report 1995, Lausanne, Switzerland.

ISO (International Organization for Standardization) (1993), Vision 2000. A Strategy for International Standards Implementation in the Quality Arena Diuring the 1990s, Geneva.

ISO 9000 News (1996): The Mobil Survey (Fith Cycle) of iso 9000 and Environmental Certificates Awarded Worldwide, No. 6, Geneva, Mobil Europe Ltd., August.

ISO/UNCTAD/OATT (International Organization for Standardization/United Nations Conference on Trade and Development/General Agreement on Tariffs and Trade) (1993): IsO 9000 Quality Management Systems: Guidelines for Enterprises in Developing Countries, Geneva.

Kaplinski, R, (1993): Notes on the implementation of quality and productivity programmes in sectors of Brazilian industry. Quality and productivity in industry: New strategies in developing countries, IDS Bulletin. Vol. 24, No. 2, Brighton, University of Sussex, IDS.

- (1995): Technique and system: The spread of Japanese management techniques to developing countries, World Development, vol. 23, No. 1, Oxford, U. K., Elsevier Science Ltd., January.

KID (Kwaliteitsdienst Foundation for Quality Services) (1996): Betere resultation door TQM, Magazines Specifiek, Rotterdam, September.

Lall, S. (1995): Governments and industrialization: The role of interventions in the 1990 s, preliminary version for the ECLAC/IDRC-UNU/INTECH Conference on Productivity, Technical Change and National Innovation Systems in Latin America in the $1990 \mathrm{~s}$, Santiago, Chile, August.

Lefiero, J. (1995): Reingeniería: Gerencia para la globalización, Revista Rumbo, San José, Costa Rica.

Maas, J. (1992): Innovatie en bebeersing in balans, Sigma Magazine, No, 3.

MacDonald, J. (1995): Together TQM and business process reengineering are winnters, TQM Magazine, vol. 7 , No. 3 .

Nakamura, T. (1992): De ontwikkeling van het kwaaliteitskostensystem, Sigma Magazine, vol. 18 , No. 5.

OECD (Organization for Economic Cooperation and Development) (1993): Small and Medium-sized Enterprises: Technology and Competitiveness, Paris.
Pandora, D. (1989): Quality Management as a Competitiveness Tool, Delft, Netherlands, Technical University Delft.

Porter, M. (1980): Competitive Strategy: Techniques for Analyzing Industries and Competitors, New York, The Free Press.

$Q$ Review (1993): ISO 9000 boosts industry performance says market survey, News from Lloyd's Register Quality Assurance Ltd., London, November.

Ramos, A. (1995): Hacia la calidad total: la dlfusión de las normas ISO 9000 en la industria argentina, ECLAC Office in Buenos Aires.

Ramos, J. (1996): Política industrial y competitividad en economias abiertas, Desarrollo Productivo, No. 34, LC/G. 1928, Santiago, Chile, ECLAC.

Rauter, R. (1992): Calidad con productividad: ol desafio de los affos noventa y del nuevo milenio, LC/R. 1198, Santiago, Chile, ECLAC.

Reinecke, R. (1996): Innovation, flexibitization and social exclusion in advanced developing countries: General considerations and empirical research, Santiago, Chile, International Labour Organisation (ILO), mimeo.

Schuurnan, H. (1997a): Quality Management and Competitiveness. The Diffusion of the ISO 9000 standards in Latin America and Recommendations for Government Strategies, Santiago, Chile, ECLAC.

(1997b): Quality Management, sso 9000 and Govermment Programmes, Santiago, Chile, EClAC.

Shaiken, H. (1994): Advanced manufacturing in Mexico: a new international division of labor?, Latin American Research Review, vol. 29, No. 2, Chapel Hill, NC, Latin American Studies Association (LASA).

Spitzer, R. (1993): Valuing TQM through rigorous financial analysis, Quality Progress, July.

Tiv Rheinland Chile (1995): Correspondence with $C$. Wagener, Santiago, Chile (not published).

Technovation (1994): The Brazilian National Quality Award: Sharing some best practices of the winner in 1993, Technovation, vol. 14, No. 10, Ansterdam. Netherlands, Elsevier Science Publishers B. V.

Van de Broek, H. (1991): Algemene Indrukken uit Kwaaliteitskundige Onderzoeken. Netherlands, Wolters Noordhof.

Vispo, A. (1994): Tecnologias de organización y estrategias competitivas, ECLAC Office in Buenos Aires.

Wildschut, E. (1993): Time Based Competition: Strategic Advantage for Shorter Enterprise Processes, Netherlands, Kluwer Deventer.

Winchell, W. (1987): Quality cost analysis: Extend the benefits, Quality Progress, September.

Zairi, M: (1996): Benchmarking: A process-driven tool for quality improvement, TQM Magazine, vol. 7, No. 3. 